\title{
Clinical findings of the phakomatoses: Neurofibromatosis
}

\author{
Mark Quigg, MD, MSc; Robert S. Rust, MD; and James Q. Miller, MD
}

The two common types of neurofibromatosis (NF) are genetically and clinically distinct diseases, each of which promotes the growth of neurofibromas and schwannomas that arise in the myelin nerve sheaths of peripheral or cranial nerves. Other tumors may arise from a variety of tissues including meningiomas, optic gliomas, and ependymomas. Both NF1 (chromosome 17q) and
NF2 (chromosome 22q) are dominantly transmitted, with half of cases arising from new mutations. Diagnostic criteria for NF1 and NF2 have been developed by consensus. ${ }^{1}$ Physical features and neuroimaging of NF are shown in figures 1 and 2 .

\section{Acknowledgments}

The authors thank C. Douglas Phillips, MD of the Department of Radiology and
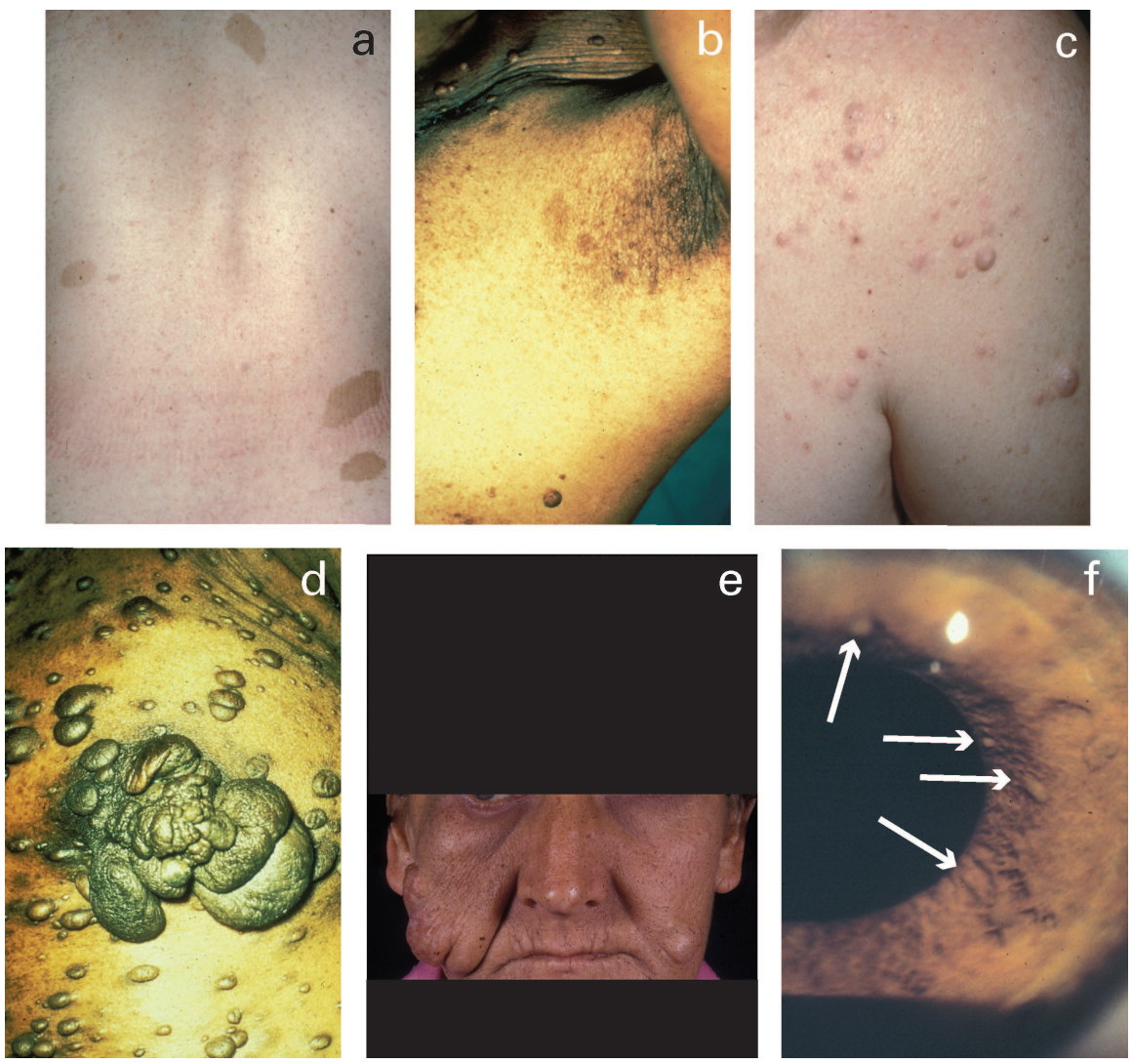

Beatriz Lopes, MD of the Department of Pathology for their contribution of images.

\section{References}

1. Stumpf D. National Institutes of Health Consensus Development Conference: Neurofibromatosis. In: Statement 6; 1986: 1 .

2. Braverman IM. Nervous disease. In: Skin Signs of Systemic Disease. Philadelphia: WB Saunders; 1998: 548-576.

3. Rust RS. Neurocutaneous disorders. In: Noseworthy JH, ed. Pediatric and Adolescent Neurology. London: Martin Dunitz; 2003: 16461680.

Figure 1. (A) Café au lait (CAL) macules on the back of a six-year-old boy; six or more that are $>5 \mathrm{~mm}$ in size in prepubertal children support a diagnosis of $N F 1,{ }^{1}$ being present in $80 \%$ of cases by two years and $100 \%$ by ten years. (B) This adult has characteristic "axillary freckles" $(1-4 \mathrm{~mm})^{2}$ as well as larger CALs (found in $70 \%$ of NF1 by ten years). The inguinal region is also a common site for freckles. In some individuals, these small CALs become more confluent. (C) Multiple cutaneous neurofibromas may be found in NF1 (5\%-10\% by three years ${ }^{2}$. They may arise anywhere in the skin. When small, invagination of these soft lesions with a finger discloses a "button-hole"-like orifice at the base. Two or more support a diagnosis of NF1. (D) Plexiform neurofibromas, present in 15\%-30\% of NF1, arise in a diffuse manner that involve multiple nerves, typically but not limited to the inguinal, or in this example, the shoulder region, and may be associated with cutaneous hyperpigmentation and skin laxity. (E) Patients with periorbital neurofibromas may develop visual changes resulting from diplopia, glaucoma, and amblyopia. (F) Lisch nodules (arrows), yellow-brown hamartomas within the iris, are found in 80\% of NF1 cases by ten years. ${ }^{2}$

From the Department of Neurology, University of Virginia, Charlottesville, VA.

Disclosure: The authors report no conflicts of interest.

Address correspondence and reprint requests to Dr. Mark Quigg, Department of Neurology, Box 800394, Health Sciences Center, University of Virginia, Charlottesville, VA 22908; e-mail: Quigg@virginia.edu 

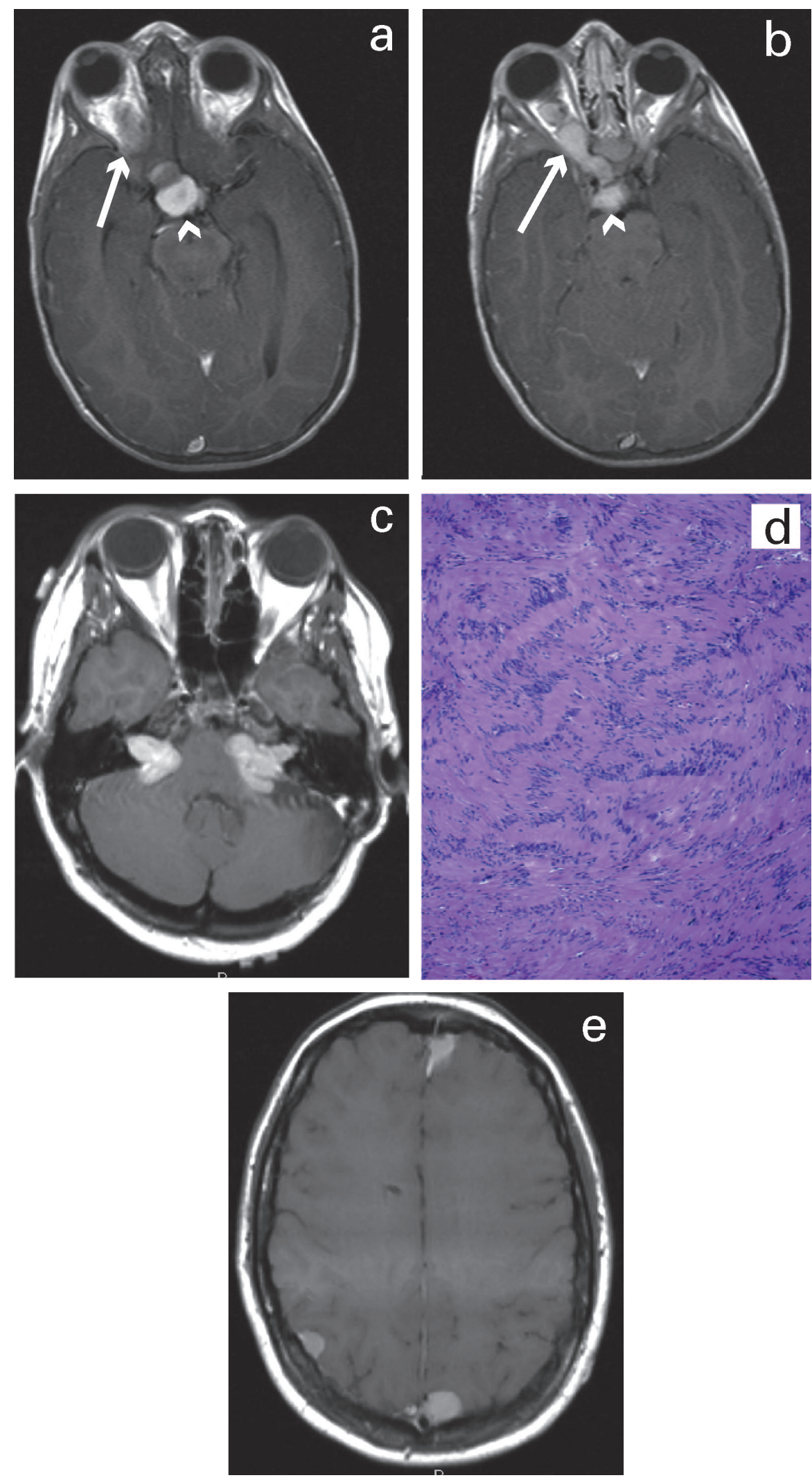

Figure 2. (A and B) Right optic nerve gliomas (arrows) that involve the optic chiasm (arrowhead) on axial T1weighted MRIs with contrast in an asymptomatic adult with NF1. These occur about in 10\%-20\% of patients with NF1 and are usually discovered in symptomatic children. They are rarely symptomatic if discovered after age ten. ${ }^{3}(C)$ Bilateral cranial nerve VIII schwannomas on axial T1weighted MRI with contrast are the hallmark of NF2. Unilateral acoustic schwannomas may occur in NF1 but when bilateral are diagnostic of NF2. (D) Photomicrograph of a resected acoustic schwannoma shows characteristic "Verocay bodies"-palisades or whorls of cylindrical or rod-shaped nuclei. (E) Multiple meningiomas, as seen in this adult, on contrasted T1weighted axial images, occur more commonly in NF2, as do astrocytomas or ependymomas. 


\section{Neurology}

\section{Clinical findings of the phakomatoses: Neurofibromatosis \\ Mark Quigg, Robert S. Rust and James Q. Miller \\ Neurology 2006;66;E23-E24 \\ DOI 10.1212/01.wnl.0000203645.25173.70}

\section{This information is current as of March 27, 2006}

\section{Updated Information \&}

Services

Permissions \& Licensing

Reprints including high resolution figures, can be found at: http://n.neurology.org/content/66/6/E23.full

Information about reproducing this article in parts (figures,tables) or in its entirety can be found online at:

http://www.neurology.org/about/about_the_journal\#permissions

Information about ordering reprints can be found online:

http://n.neurology.org/subscribers/advertise

Neurology ${ }^{\circledR}$ is the official journal of the American Academy of Neurology. Published continuously since 1951, it is now a weekly with 48 issues per year. Copyright . All rights reserved. Print ISSN: 0028-3878. Online ISSN: 1526-632X.

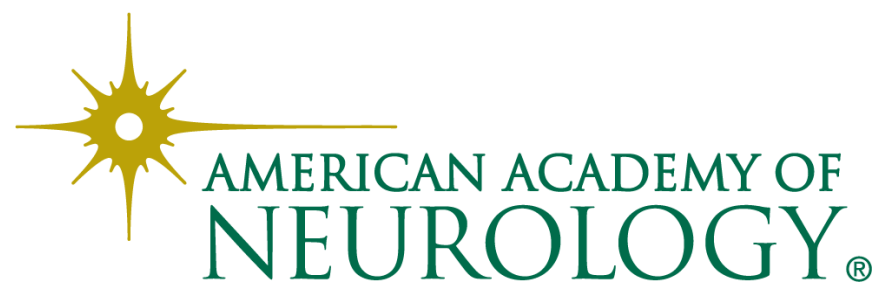

